\title{
Global Ambitions and Local Compulsions: Exploring the Paradoxes Confronting Meghalaya in North East India \\ Susmita Sen Gupta*
}

Department of Political Science, North-Eastern Hill University, Shillong, India

\begin{abstract}
Globalization has undoubtedly emerged as one of the leading characteristics of the contemporary world. On the one hand, it has ushered in a new and promising era marked by rapid movements of large volumes of money and the increased volume of trade and has led to a growing density of market relations resulting in faster growth and creating unprecedented new opportunities for sustainable development and poverty reduction. At the same time, it also implies increased risk, uncertainty and vulnerability because of the widely fluctuating flows of capital around the globe and unstable exchange rates.

In the context of the above, the paper proposes to examine the situation in Meghalaya, a state located in North East India and argues that globalization which entails greater interaction among cultures has generated a feeling of insecurity among the indigenous population, thereby consolidating the urge for preserving the indigenous culture from being invaded by the powerful waves of globalization. Globalization has undoubtedly led to increased transnational flows such as migration. The enhanced volume of migration has already unleashed the forces of ethnic backlash in most states of northeast India. In the context of the above, the paper will focus on the impact of greater global investment possibilities and migration of labor on local communities in Meghalaya in terms of the perceptions of regional political parties and local pressure groups. It will also examine the contradictions arising out of the desire to explore opportunities to capture the benefits of globalization on the one hand and the compulsion to protect local identities and heritage on the other. The paper has been divided into five sections. The first section focuses on the development constraints in northeast India and the difficulties in the land acquisition process. The second section highlights the global investment potential in Meghalaya and examines local resistance to the same. The next section discusses some initiatives taken by the Government of Meghalaya to attract investment. The fourth section examines local perspectives on uranium mining in Meghalaya. The fifth section comments on the impact of migration in northeast India as a whole and Meghalaya in particular. The fifth and the final section summarize the concluding observations of the paper in terms of the contradictions emanating from the parallel processes of globalization and local protest movements.
\end{abstract}

Keywords: Globalization; Development paradigm; Special economic zones; Migration; Nativism and ethnic polarization

\section{Development Constraints in Northeast India}

It may be observed that the north eastern region of India has its own opportunities and constraints, strengths and weaknesses and needs and priorities, but the development initiatives so far have followed the national perspectives of development and the region continues to be backward in spite of some special packages and programs and institutions like North Eastern Council (NEC) and Development of the North Eastern Region (DONER). In the era of globalization and liberalization, there is a shift in development paradigm, from top down approach to bottom up, from people around development to development around people, from emphasis on growth factor to concern for sustainable development and from centralized initiatives to democratic decentralization in making economic decisions [1]. Associated with such a shift in development paradigm is changing development initiatives in North East India. It may be noted in this context that growing presence of Multinational Corporations, an invariable concomitant of the globalization process, is yet to take place in the North East in a big way, primarily because ethnic strife and insurgency stand in the way of a favourable investment climate. Moreover, the difficult terrain and transport bottlenecks have kept the North East starved of business. To offset this disadvantage, the Government of India introduced the North East Industrial Policy (NEIP) in 1977. This policy offers tax holidays and a range of subsidies to companies setting up industries in the region. But in spite of such concessions, business tycoons still shy away from investing in the region. Companies like Tata's are yet to venture to the North East. Only the Infotech wing of the company, viz., Tata Consultancy Services (TCS) has started operations at the IIT Premises in Guwahati. While Assam is showing some amount of openness to woo business to the State, other states of the North East have not, however, been as spontaneous. This is because land continues to be the major bone of contention especially in tribal areas where it is owned by communities and individuals. The Land Transfer Act in States like Meghalaya and Nagaland has been a handicap to the setting up of industries [2]. To circumvent this obstacle, several companies which require land beyond the industrial estates acquired by the government, have resorted to benami transactions and have acquired land in the name of tribal partners. Such clandestine acquisition of land by companies threatens to snowball into a major crisis like the Singur situation in West Bengal and is integral to the nationwide debate on the viability of Special Economic Zones (SEZ).

\section{Global Investment Potential and Resistance to Industrialization in Meghalaya}

An enquiry into the possible impact of greater global investment in the North East leads to another interesting phenomenon. What strikes a researcher in this context is that in Meghalaya, a State of the North East, there exists a deep-rooted political resistance to any move for industrialization, lest it leads to influx from outside the State [3]. Apart

*Corresponding author: Susmita Sen Gupta, Department of Political Science, North-Eastern Hill University, Shillong, India, Tel: +91-94361-10674; E-mail: ssg62@rediffmail.com

Received April 27, 2016; Accepted May 03, 2016; Published May 05, 2016

Citation: Gupta SS (2016) Global Ambitions and Local Compulsions: Exploring the Paradoxes Confronting Meghalaya in North East India. Int J Econ Manag Sci 5: 353. doi:10.4172/2162-6359.1000353

Copyright: (c) 2016 Gupta SS. This is an open-access article distributed under the terms of the Creative Commons Attribution License, which permits unrestricted use, distribution, and reproduction in any medium, provided the original author and source are credited. 
from the regional political parties who have voiced their concern over large -scale industrialization, youth and student organizations have also joined the bandwagon. It may be noted in this context that even extension of railway network to the hill state of Meghalaya has been stubbornly resisted by various socio-political forces on the pretext of influx which had led to the exclusion of Meghalaya from India's railway map until recently. In 2015, railways were extended up to Mendipathar in Garo Hills. But railheads are conspicuous by their absence in the Khasi and Jaintia Hills of Meghalaya. As a matter of fact, opposition from the Khasi Students' Union (KSU) resulted in abortion of what should have been Meghalaya's first railway project in Byrnihat in 1988. It was later learnt that the students' body acted at the behest of the truck owners' lobby who wanted no competition to their business. As a result, Meghalaya coal is today traded as Assam coal once it is loaded on to railway wagons in that State [4]. This is a classic example of a students' body assuming a hegemonic role as pseudo-representatives of the larger population so much so that a popularly elected government has systematically succumbed to pressures from such exclusive groups, making a mockery of all democratic norms.

\section{Government Initiatives to Attract Investment}

In the context of the above, it may appear that Meghalaya does not harbor any global ambitions. But the reality is that a gradual transformation of the protectionist psyche in favour of an open economy is becoming perceptible. This was reflected at the Seminar on "Business Practices in Meghalaya" held in Mumbai on the $28^{\text {th }}$ of August, 2008, in order to promote the 'Scotland of the East' as a good place to invest in. A high-level team of the Government of Meghalaya headed by the Chief Minister, Dr. Donkupar Roy, invited investors from across the country, hardselling the State's potential for development. A number of private companies showed interest to invest in Meghalaya in different Sectors starting from education to tourism during the daylong seminar [5]. International Banks like ABN Amro and Deutsche were interested in micro financing and skill development respectively. It seems that the Government of Meghalaya has identified tourism, information technology, education, health, mineral resources, horticulture, food processing and floriculture as the most potential Sectors and has promised incentives for investors in these Sectors. Addressing the $4^{\text {th }}$ North East Business Summit in Guwahati, the chief Minister of Meghalaya called upon the Government of India to facilitate trade with neighbouring Bangladesh through the State in a much greater scale for mutual benefits. In this connection, it may be noted that the Minister for Development of North Eastern Region (DONER) sought to assure the investors by stating that the security concern should not be allowed to come in the way of investment for tapping huge pool of natural and mineral resources and infrastructure Sectors in the region which is India's gateway to the prospering economies of South East Asia [6]. In the Summit, the Chief Ministers of the North Eastern States demanded waiving of the Restricted Area Permit (RAP) and Protected Area Permit (PAP) System now in vogue in the region in case of foreign visitors, as these are major deterrents to promotion of the most potential tourism Sector in the region. However, in spite of the initiatives taken by the State Government of the region to facilitate investment proposals, resistance from local pressure groups continues to mount in the form of demands for ensuring job guarantees for the indigenous youth. In view of the above, the dilemma for the prospective investors will be to accommodate such demands to a certain extent, even though trained manpower may not be available locally to cater to the technical requirements of a sophisticated industry [7].

\section{Uranium Mining and Local Sensitivities}

A glaring example of local compulsions taking precedence over global ambitions can be seen in the context of the debate over the viability of the proposed uranium mining in Meghalaya. The debate assumes significance in view of the current demand for uranium in the country as an alternative source of energy and also in view of the proposed Indo-US nuclear deal. Pressing ahead with its proposal to mine uranium in Meghalaya, the Union Government held a series of meetings with State political leaders and NGOs on the thorny issue and reiterated that it was awaiting the green signal from the Meghalaya Government to the proposed uranium mining project at Mawthabah, West Khasi Hills, in view of the country's requirement of 20,000 MW of nuclear energy [8]. The Union Cabinet Secretary K. M. Chandra Shekhar who held separate meetings with leaders of Khasi Students' Union (KSU), Federation of Khasi, Jaintia and Garo People (FKJGP), Garo Students' Union (GSU) and other local organizations admitted that a consensus was yet to evolve on the issue of uranium mining in the State. While the KSU has been the most vocal in its opposition to the project, the FKJGP maintains that the issue of health hazard from uranium mining should be addressed properly before arriving at a final decision on the project. GSU and West Khasi Hills Students' Union seem to support the project provided it brings maximum benefits to people of Mawthabah and adjoining areas in terms of infrastructure and employment opportunities. It may be noted that no consensus has emerged on this issue even within the ruling coalition and two allies of the Meghalaya Progressive alliance, viz., Hill State People's Democratic Party (HSPDP) and Khun Hynniewtrep National Awakening Movement (KHNAM) have continued to oppose the opencast uranium mining. Interestingly, the debate on uranium mining has triggered some positive and enlightened thinking among a section of the educated elite of Meghalaya. One such view asserts that the presence of uranium provides Meghalaya with a unique bargaining power visà-vis the centre, in order to improve its backward infrastructure and emphasizes the need to infuse a healthy dose of inclusive progressive nationalism into the prevailing tehno-centric, purely regional outlook, not only for the sake of energy security of the country, but also for the good of the local people.

Thus, the issue of uranium- mining reflects contradictions between the developmental agenda of the Indian State and ethnic sensitivities [9]. The issue has become significant from another perspective. The civil society resistance against uranium mining in Meghalaya is ideologically connected with the worldwide movement against nuclear proliferation and is also an integral component of the anti-state movement against the overall developmental agenda of the Indian State.

\section{Migration and Nativist Movements}

Another inevitable consequence of globalization is an increase in transnational flows such as migration. In States of North East India, presence of migrant labourers has already precipitated a crisis, leading to a number of nativist movements, juxtaposing the migrants against the 'Sons of the Soil', because migrant labourers are being perceived as posing a threat to the indigenous labour force. Myron Weiner has identified five conditions for such nativist movements, viz., presence of migrants from outside the cultural region, cultural differences between the migrants and the local community, immobility of the local population, in comparison to other groups in the population, a high level of unemployment among the indigenous middle class and a substantial portion of middle class jobs held by culturally alien migrants and a rapid growth of educational opportunities for the lower middle classes. 
Weiner also points out that development of either a regional or national identity is a pre-condition to the development of nativism. Nativism, according to Weiner, is that form of ethnic identity that seeks to exclude those who are not members of the local or indigenous ethnic group from residing and working in a territory because they are not natives. $\mathrm{He}$, therefore, considers ethnic selectivity as the characteristic feature of nativism. As the spread of globalization in the North East is likely to enhance the volume of migration, nativist movements have gained momentum in most of the States of the region including Meghalaya, thereby unleashing the forces of ethnic backlash against culturally alien migrants. It may be noted that student and youth organizations of Meghalaya have been in the forefront of mobilizing the support of the indigenous population in the crusade against migrants. This, in turn, has led to counter mobilization by similar organizations of migrants in the struggle for survival, accelerating the process of ethnic polarization in this part of the country.

\section{Concluding Observations}

In view of the above, this paper would like to argue that there is no alternative to the powerful forces of globalization and the people and policy-makers at the local level have no other option but to learn to live with it. It is necessary, therefore, to explore the possibility not of turning away from globalization to exclusivism, but to launch a struggle for a new global socio-economic order which gives priority to the values of equity, justice and local sensitivities, while capturing the maximum benefits out of the unprecedented new opportunities that globalization promises to offer.

In the context of Meghalaya, it may be argued that regional political parties and pressure groups are apparently articulating the legitimate concerns, aspirations and sensitivities of their respective ethnic communities. But a critical look into the phenomenon reveals that the rigid ethno-centric perspective of these organizations has sometimes been self-defeating for the very ethnic communities they claim to represent. For instance, resistance to railways and the setting up of large industries would be prejudicial to the larger interests of these communities in the long run, particularly in view of the fact that they do not have many alternative sources of revenue generation. Of course, some of the concerns voiced about uranium mining are genuine and need to be addressed by the concerned authorities before they seek to go ahead with the mining operations. An understanding of the contradictions between global ambitions and local compulsions in Meghalaya requires an enquiry into all these processes.

\section{References}

1. Abysk A (2002) Globalization and Human Rights, University of California Press, Irvine.

2. Baral KC (2006) 'Globalization and Tribes of North-East India' (Editorial), Indian Folklife, Serial No. 22.

3. Behera MC (2004) Globalization and Development Dilemma: Reflections from North East India, Concept publishing company, New Delhi, India.

4. Kofman E, Gillian Y (2003) Globalization: Theory and Practice (3rdedtn) Continuum International Publishing Group, New York, USA.

5. Scholte JA (2000) Globalization - A Critical Introduction (1stedn) Palgrve Mcmillan, London, UK.

6. Sen GS (2005) Regionalism in Meghalaya, South Asian Publishers, New Delhi, India.

7. Weiner M (1978) Sons of the Soil: Migration and Ethnic Conflict in India, New Jersey, USA.

8. White Paper on Globalization issued by the UK Government in 2000.

9. Namita R, Mahua D (2011) Special Economic Zone or Special Exploitation Zone: An Analytical Perspective (Case: Singur in West Bengal), Asia- Pacific Journal of Management Research and Innovation 7: 170-177. 